\title{
Chiasmatic Reversals in Blanchot's "L'idylle"
}

\author{
Deborah Hess \\ Drew University
}

O ppositional tensions create conflicting topoi in Maurice Blanchot's short fictional work, "L'idylle" (1936), published first separately in 1947, ${ }^{1}$ then with "Le dernier mot" in Le ressassement éternel (Minuit, 1951), and finally in Après-Coup followed by a postface by the author (Minuit, 1983). Blanchot's republication of this work indicates a willingness to reinterpret one of his earliest fictional works. Its initial context supports a reference to Soviet gulags; in Après-Coup Blanchot intended to extend that interpretation to Nazi death camps. ${ }^{2}$ The multiple contexts are supported by chiasmic structures on many levels: symbolic, syntactic, narrative, and topological. ${ }^{3}$

Chiasmus may be defined as any structure in which some of its elements are repeated in reverse; it expresses inversion within repetition in an envelope pattern. It is a rhetorical figure which gives validity to both sides of an oppositional situation without overtly favoring one or the other. Because of the ambiguity underlying the author's point of view, interpretation may be difficult. In the case of "L'idylle," the reader uses the historical context to help interpret the chiasmatic structures. ${ }^{4}$ Some readers have interpreted "L'idylle" in the context of Auschwitz. Sarah Kofman dedicates Paroles suffoquées "à la mémoire de mon père, mort à Auschwitz, pour Robert Antelme (who was interned in Dachau), en hommage à Maurice Blanchot" (9).

The reader also uses authorial statements to support a given interpretation. Blanchot places "L'idylle" in the context of both the Soviet gulag and Auschwitz. In the 1983 reedition of Le ressassement éternel (Après-Coup), Blanchot states in a postface: "Cela eut lieu à Auschwitz, cela eut lieu au Goulag":

Et pourtant, difficile, après coup, de n'y pas songer. Impossible de ne pas évoquer ces travaux dérisoires des camps concentrationnaires, quand ceux qui y sont condamnés transportent d'un endroit à l'autre, puis ramèment au point de départ, des montagnes de pierres, non pas pour la gloire de quelque pyramide, mais pour la ruine du travail, ainsi que des tristes travailleurs. Cela eut lieu à Auschwitz, cela eut lieu au goulag. (AprèsCoup 95-96). 
Blanchot claims not to have known of the Death Camps at the time he wrote "L'idylle": "Prophétique aussi, mais pour moi (aujourd'hui) d'une manière plus inexplicable, puisque je ne puis l'interpréter que par des événements qui sont survenus et n'ont été connus que bien plus tard" (94). ${ }^{6}$ The correlation between the récit and future events cannot be explained as a reference to a future historical event, but rather to a tension surrounding mysterious aspects of human behavior:

Mais je ne pense pas que "L'idylle" puisse s'interpréter comme la lecture d'un avenir déjà menaçant. L'histoire ne détient pas le sens, pas plus que le sens, toujours ambigu — pluriel — ne se laisse réduire à sa réalisation historique, fût-elle la plus tragique et la plus considérable. C'est que le récit ne se traduit pas. S'il est la tension d'un secret autour duquel il semble s'élaborer et qui se déclare aussitôt sans s'élucider, il annonce seulement son propre mouvement qui peut donner lieu au jeu d'un déchiffrement ou d'une interprétation, mais il y demeure lui-même et à son tour étranger. (96)

"L'idylle" expresses "the tensions of a secret": the reverse side of political power is the torture and annihilation of those lacking political rights: of foreigners or strangers ("étrangers"), anyone those in power choose to designate as "other."

Blanchot expresses through chiasmus the tensions surrounding appearances and reality, the importance attributed to the happiness of masters, and society's acceptance of tragic episodes. The title of the initial work written in 1936 alerts us to this tension: "'L'idylle,' ou le tourment de l'idée heureuse."7 The récit expresses oppositions: between solitude and society, freedom and imprisonment, beauty and ugliness, happiness and unhappiness, love and hatred, life and death. Each topos is paradigmatically expressed: the first term evokes the appearance, the second the underlying hidden reality. Appearances are deceiving. Akim wants to believe their marriage is idyllic: "Sont-ils heureux ou malheureux?" (36).

Akim represents the tension between self and society. He arrives as a foreigner ("étranger"), without family, friends, or possessions; he is hungry, exhausted, and without resources. On his arrival, he is briefly treated as a member of the society by the director and his wife, then by Piotl. Despite an initial cordial welcome, as an individual he has no value. The director metes out extraordinary punishment - death - for the crime of trying to escape. Tension exists between freedom and imprisonment. Akim seems to be free: he walks freely through the apartments of the director and his wife and expresses his thoughts readily. Despite the director's assurance, he is not free: he is forced to remain in the barracks and work in the quarry, then is locked up in a prison cell. After he attempts to escape, he is brought back by a guard, and sentenced to death.

Beauty is contrasted with ugliness. The chiasmic nature of beauty is symbolized by flowers associated with death. In the director's official rooms, a single flower evokes a guileless love: "une fleur encadrée, un objet touchant et inutile, réveillait le souvenir d'un 
amour sans travers" (23). In his apartment, Akim finds ambiguous symbols associated primarily with absence and death: "Les murs en étaient nus; des coquillages, des pierres gravées, des verres teints de couleurs aimables ornaient la cheminée et les meubles. Il semblait qu'un jeune fleuve eût coulé par ces pièces, abandonnant, sous forme d'images vitrifiées, les débris de terre et d'herbe arrachée aux prairies" (23). Flowers are an incongruous symbol at the funeral of Nicolas Pavlon, an inmate whipped to death for stealing (29). Akim reacts against the ambiguous symbols: "La solennité de la cérémonie, l'apparente tristesse des habitants qui pleuraient mensongèrement un mort étranger, la grossièreté, habilleé de fête, des détenus, inspirèrent à Akim un dégoût qui lui eût fait immédiatement quitter le cortège s'il n'avait craint un châtiment" (29-30). As the director condemned Pavlon to death, Akim finds his expression of grief through flowers "une bouffonnerie, une dérision, une vengeance d'hommes dépravés" (30). When Akim decides to marry, he buys flowers in a dilapidated shop, "une soupente dans une maison délabrée" (46). For his marriage, flowers and torches are to shine throughout the house.' At his funeral, the same flowers are heaped around his casket: "On dressa un grand catafalque dans l'entrée, et les invités restèrent pour s'associer aux funérailles. Le soleil brillaient avec un bel éclat. Les fleurs du jardin, encore à demi mouillées, s'épanouissaient" (56). Flowers are usually associated with beauty, love, and life; in "L'idylle" they are associated with ugliness, hostility, and death.

The primary narrative event is the substitution of an execution and funeral for a marriage ceremony. The substitution results from a dual plot: Akim pledges to marry while making plans to escape. When caught, his death by whipping makes his marriage irrelevant. The substitution represents a ritual shift from life to death, from union to destruction. The shift is implicit in the initial scene. When he meets the director and his wife, Akim believes they have an idyllic marriage; they inspire him to marry. In fact, their marriage is one of psychological horror: shrieks emanate from their apartments. Akim has difficulty believing reality is other than idyllic. A chiasmic relation connects the director and his wife, Nicolas Pavlon and the community, and eventually Akim and the community. However the idyllic community hides an unspeakable reality.

The narrative turns around a series of chiasmic reversals. These shifts are alluded to in the text: Akim refers to "sa propre métamorphose"; an execution takes the place of a marriage celebration (53). In preparation for his wedding, curtains are changed twice daily: "Et puis, l'on changeait de tentures deux fois dans la journée; au lieu des rideaux gris et noirs du matin qui signifiaient la tristesse d'un homme à jamais éloigné de son pays, on exposait des tentures bariolées, où s'épanouissaient des ornements et des emblèmes délicats" (47). This parallels a change in status: "l'étranger mourait aux premières heures et c'est un familier qui, l'après-midi, prenait sa place" (47). Chiasmic shifts result from the gap between appearance and reality. On his arrival, a guard warns "l'étranger": "Ne vous fiez pas aux apparences" (9).

A series of chiasmic statements structure the novel. The underlying nature of reality fails to correspond to appearances. An idyllic surface is inevitably betrayed. This is 
translated by a chiasmic reversal at narrative, symbolic, and stylistic levels of $L$ 'idylle. "'Vous allez m'en vouloir, mais c'est la règle. On n'échappe pas au spectacle $d u$ bonheur" " [italics mine] (9), a guard greets "l'étranger" on his arrival. In his warning, the guard substitutes "bonheur" for "malheur." The guard's warning redefines the expected meaning of the word "le bonheur," for 'happiness' does not fit with the other words in the sentence: "vous allez m'en vouloir," "c'est la règle," "on n'échappe pas" (9). The narrator's first impression is one of mixed signals: in a "jardin vide" he meets a young woman who appears well-fed and flourishing, "aux joues rondes, aux mains potelées" (9). She welcomes the narrator reassuringly: "Ne craignez rien, la maison vous est ouverte" (9). The guard warns him again before leaving: "Mais je vous en prie, suivez mon conseil: ne vous fiez pas aux apparences" (9). The guard gives a context for interpreting the young woman's welcome. The reader receives ambiguous signals - the guard's warning and the young woman's welcome. The opening scene serves as frame to express Blanchot's interpretive intentions: reality is not what it appears. He rejects an empirical or objective view of reality in which a superficial external aspect reflects underlying substrata, in which phenoma reflect the underlying nature of things. The narrative development of $L$ 'idylle continually surprises the narrator; he will not anticipate the unexpected reversals. The twists result from the indeterminate nature of events which cannot be predicted in advance.

A chiasmic reversal is often indicated by "mais": the narrator had been told, "vous allez m'en vouloir, mais c'est la règle" [italics mine] (9); he is sent to a quarry to work under the supervision of a giant who is "très laid mais débonnaire, toujours inquiet et agite" (15). The opposition between "très laid" and "débonnaire" is striking, especially since both are irrelevant to the situation. "Débonnaire" is most improbable, as the men work from morning to night under a blazing sun, dragging boulders into a vast pit. The improbable details are part of a larger paradoxical situation in which many elements do not belong:

Le travail consistait à charroyer dans une vaste fosse les pierres qu'arrachaient chaque jour à la montagne les ouvriers de la ville sous le soleil, c'était une tâche harassante, harrassante et inutile. Pourquoi jeter dans ce fossé les pierres que des voitures spéciales emportaient ensuite sur les routes? N'aurait-on pas pu les charger aussitôt après leur extraction, quand on les avait réunies en tas? Mais il fallait bien faire travailler les vagabonds, et un travail de vagabond ne pouvait servir à grand-chose. $(15-16)$

The useless tasks carried out under extremely difficult conditions further estrange the foreigners. The region is arid, burned by the sun by day, silent and cold at night; workers are allowed only a few drops of alcohol each day.

Akim falls ill, and the director comes to see him. Surprised by the narrator's illness, he remarks: “QQu'avez-vous ... pourquoi cette subite indisposition dans ce pays où l'on se porte si bien? Etes-vous sujet à de tels malaises?"' (18). Given his working conditions and 
lack of water, Akim's illness is certainly understandable. He accuses the director of treating him savagely: "Un chien, une charogne auraient eu droit à plus d'égards" (18). He says he will always remember the others' "hospitalité," a word he uses for its antonym. Surprised, the director replies: "J'ai fait tout ce que j'ai pu pour adoucir votre sort. Quelque chose vous a-t-il manqué?" (18). Because Akim angrily screams at the director to go away, he is placed in a prison cell: "il continua à jouir des meilleurs soins, mais ne recevait, par un soupirail, qu'une faible lumière, séparé, semblait-il, du monde à jamais, tant le silence était grand" [italics mine] (18). "Les meilleurs soins" contradict the faint light and silence recalling the nights in the quarry; the expressions are set off by "mais." The nurse tries to comfort him: "Naturellement, lui disait-il, il est dur d'être privé de liberté. Mais est-on jamais libre? Peut-on faire ce qu'on veut? Et il y a tant d'autres raisons d'être malheureux" [italics mine] (18). The first statement, "it is difficult to be deprived of freedom' is reversed by the second denying freedom's existence; the last negates his feelings.

After being released from prison, an old man remarks: "Chacun ici a sa prison, mais dans sa prison chacun est libre" [italics mine] (19). ${ }^{8}$ Akim's comrades deny the reality of his imprisonment and the unusual nature of his punishment. By defining incarceration as freedom, its meaning is inverted. Like the fictional work and its title, the actual situation is not idyllic, only the narrator's or reader's perception. The first part of the chiasmic statement is a fact: "chacun ici a sa prison": this is true for the inmates; it is also true for the supervisor and the director and his wife who conform their actions to preconceived roles. The "mais" and the following subordinate clause invert the first part; "libre" means the opposite of "prison." The resulting chiasmus is puzzling, as the semantic units have been distorted to a maximum.

When he returns from his solitary confinement, Akim expects a peaceful reunion with his fellow inmates; instead, he receives a raucous greeting. "Il se couch a dès son retour au hangar, résolu à demeurer seul parmi ses comrades. Mais tous l'entourèrent et il dut leur tenir tête en contredisant d'une voix aigre tout ce qu'ils disaient" [italics mine] (21). The narrator is as alone in a crowd as he was in prison. He is set apart from his fellow inmates by his active and rebellious stance: he is the only member of the community to openly express his point of view, the only one to directly challenge the director or to try to escape. The challenge is forceful, indicated by the words "contredisant," "voix aigre," "tout." He is unable to ignore the discussion around him: "il dut leur tenir tête." Akim represents the individual who challenges the group and the system.

The director and his wife symbolize the state. Ostensibly, their marriage is idyllic; in fact, it is not: "Ils ont cru que l'amour les attirait l'un vers l'autre, alors qu'ils se détestaient. Ils ont senti à certains signes qu'ils étaient liés tous deux au même destin, mais c'était par le désir de se déchirer dans la mésentente et les tourments ... ils ne pouvaient que continuer à s'aimer pour continuer à se hä̈r" [italics mine] (28). Underneath an apparently idyllic surface seethes continual conflict. Rather than an attraction based on love, there is hatred. "Attirait" and "liés au même destin" are opposed to "le désir de se 
déchirer" and "la mésente et les tourments." The parallelism of the last clause indicates the complete reversal in their feelings: "continuer à s'aimer"; "continuer à se haïr." The clause has no resolution. Their marriage represents the hostile feelings under the idyllic surface of the hospice. Because he is uncertain how to interpret events in the hospice, the narrator continually tries to verify the state of others' feelings. Akim tries to ascertain whether appearances or hidden aspects characterize the director's marriage and hence the nature of the society where he now resides. The chiasmatic sentences can also be read as reversals. Each sentence implies that positive action produces a negative result. Other examples of frustrated positive actions are Akim's attempts to be congenial with the director and his wife, to work up to his capacity in the quarry, and to marry. Because good intentions seem to produce harmful results, a dual intrigue develops inside and outside the hospice relating to Akim's public and private behavior. His revolt and escape are planned well in advance: he frequently leaves the hospice to walk about the town; he visits the bookseller, seeking maps of the town. Akim discovers that outside the hospice, reality is dual. The wind outside is at times pleasant, at others plague-ridden: "Par bouffée arrivait une odeur âcre, tantôt excitante et agréable, tantôt pestilentielle" (35). An old man introduces Akim to his nieces, young girls who are "laides mais agréables" (39). A repellent exterior belies an attractive inner nature. Their good nature may have greater long-term importance, but in this case it is desirable that the girls be attractive; as Akim decides to marry one of them.

Akim symbolizes the outsider. "Vous apprendrez dans cette maison qu'il est dur d'être étranger. Vous apprendrez aussi qu'il n'est pas facile de cesser de l'être"' [italics mine] (41). To be an exiled person is to feel continually excluded, to be in a position of constant reversal because customs and rules differ. Just as a guard had initially warned him on his arrival about the gap between appearances and reality, Akim warns new arrivals, "des hommes de mauvaise mine, accablés de fatigue, hagards," about the difficulties of being an outsider. To be one is to be in a state of permanent opposition to society: if the newcomers adapt to the new society, they will be sent back to the country they left. " $\mathrm{Si}$ vous regrettez votre pays, vous trouverez ici chaque jour plus de raisons de le regretter; mais si vous parvenez à l'oublier et à aimer votre nouveau séjour, on vous renverra chez vous, où, dépaysé une fois de plus, vous recommencerez un nouvel exil'" (41-42). Inmates of the hospice are in a state of constant reversal, of constant exile. They represent the refugee who will always be outside social norms.

An unpleasant appearance may hide an agreable reality. Like the supervisor, "très laid mais débonnaire" (15), like Piotl's nieces, "des jeunes filles laides mais agréables" (39), his fiancee's family's rough exterior belies an inner kindness: "C'étaient des hommes grossiers, au visage marqué de coups; mais une bonté naïve se dégageait de leurs traits . . ." (48). Both aspects of reversal characterize life in the hospice: an idyllic appearance hiding a frightening reality, and the opposite: a disagreeable appearance covering a pleasant nature. In both cases, revelation of the essence behind appearances is unexpected. The narrative does not develop linearly, but reveals surprising twists. Akim becomes engaged, but never intends to marry his fiancee: he uses his engagement as cover for his escape. To find his 
way through the labyrinthine town, he obtains a map. Yet the town does not correspond to the map: "Le plan qu'il avait tracé le matin était présent à son esprit, mais la ville avait changé" (51). The town's layout appears different either because the map was very old, or because very recent clearing, renovation, and construction have changed the town's appearance, or because Akim's psychological state is unable to accurately perceive objective reality. The latter explanation seems most likely. Disoriented, Akim panics, loses his bearings, and blindly rushes about. The lack of correspondence between the map and the town symbolizes Akim's status as outsider when he arrived. Physical and geographical markers are important anchors for personal identity. They symbolize the importance of a correspondence between a mental conception and its implementation. The interaction between mind and the world, subject and object, enables the individual to feel in control of his or her environment. The altered appearance of the labyrinthine town produces a loss of control.

Punishment is infrequent but necessary: "Les châtiments sont rares, reprit le directeur, mais ils sont nécessaires" [italics mine] (52). In L'idylle, neither is the case: punishment occurs often, and is unnecessary because unjustified. Akim will be punished not because he is guilty, but for disturbing the order of the house. The director scolds him sternly: "Vous vous êtes rendu coupable d'une fâcheuse action. ... Vous avez trompé une jeune fille en lui proposant le marriage, alors que vous ne songiez qu'à disparaître. Vous nous avez trompés en nous faisant relâcher notre surveillance, sous le prétexte de ces noces qu'il fallait préparer. Vous avez troublé l'ordre de la maison" (52). The director accuses Akim of tricking the hospice into relaxing its surveillance, and a young girl into believing he wanted to marry her; in fact the hospice and the director have been guilty of imposing an unjustified and erratic law on the inmates.

The director admits that justice is relative: "J'ignore comment dans votre pays fonctionne la justice; chacun a ses usages et l'on n'imagine pas facilement les coutumes des autres" (52). The director uses the relativity of justice not as a basis for clemency, but for capricious punishment. Akim will be whipped ten times by the supervisor, who apologizes for his actions, "avec une sincérité et une tristesse inhabituelle" (53). This recalls Nicolas Pavlon's similar whipping by the supervisor, which Akim witnessed. Nicolas was also condemned to be whipped ten times, and for a similarly minor infraction: walking naked through the town when he had a high fever and was either overheated or in a hallucinatory state. The episode is presented not from Nicolas's point of view, but from that of the perpetrator (the supervisor) and the spectator (Akim): "Akim vit combien était inhumaine cette épreuve de la flagellation. Au dixième coup, la victime s'épanouit et le bourreau, épuisé par sa violence, se mit à frissonner, comme si un poison lui avait soudain refroidi le sang" (26-27). Pavlon dies as a result of the whipping. The second whipping is not "inhabituelle," but part of a pattern. The supervisor does not feel genuine sadness; if he did, he would not carry out the punishment, as justice is capricious. "Le surveillant lui demanda pardon, mais avec une sincérité et une tristesse inhabituelle" (53). "Pardon" does not fit the situation: if the narrator is guilty of the crime, it is he who should be asking for forgiveness. 
The supervisor's doing so indicates he knows the punishment is unjustified.

The unexpected substitution of an execution for the marriage ceremony astonishes and frightens the other inmates. The point of view is reversed: it focuses not on the victim, but on the executioner; meting out punishment is more trying then receiving it. After the first blow, Akim loses consciousness; at the third, he recovers enough to suffer horribly. After each blow Akim waits for the supervisor to gather strength, not knowing whether he will survive the next one. After the whipping, the director leads Elise, Akim's fiancee, to his bedside, and asks Akim if he is suffering, if he wants anything, and if he can assist the dying man. Akim dies: the guests invited for his marriage ceremony stay to mourn at his funeral. The coffin, the funeral, and the fiancee's tears, "la mort et les larmes," are intermingled with symbols representing life and beauty: the brilliant sunshine, the luxuriant blooms in the garden. The director's wife gets up to carry out her duties as mistress "aux reflets d'une foi inébranlable" (56). Louise's dominance is juxtaposed with Akim's death and his weeping fiancee. Death has triumphed over love, duty and mechanical gesture over sincerity, the director and his wife over Akim and Elise. The guard's initial warning has been realized.

\section{Notes}

${ }^{1}$ La licorne (Spring 1947): 33-58.

${ }^{2}$ The first European state to set up a long term concentration system was the Soviet Union. From 1920 on, the Tchéka, the Soviet secret police, began to deport counter-revolutionaries without trial. By 1922 there existed about twenty concentration camps in various Russian provinces. The first work camp was created in 1923 in the Solovietski islands. In May 1928 the central executive committee of the Soviet Union decreed the generalized use of work for persons requiring social protection. The number of prisoners in the Solovietski camp amounted to 6,000 in $1927,30,000$ in 1928 , and reached 650,000 by spring, 1930. From 1929 , the beginning of the era of five-year plans, the Soviet state decided to use concentration camp prisoners for large-scale construction projects for the Socialist State. In the 1930s prisoners were used to build canals to the White Sea and the Moscow-Volga canal. They also built roads, railway lines, and industrial plants in the Urals and in Siberia. In 1934 the camps were placed directly under the Guépéou, the political police, which thus became the largest industrial employer. In spite of the considerable mortality rate, the total population increased following deportations of the koulaks (1929-32), and of victims of the purges from 1935-38. It has been estimated that from 1935 on, from six to ten million persons were imprisoned in the Soviet camps. The existence of these Soviet camps was known in the West from the early 1930s. In Nazi Germany, as of 1933, several concentration camps existed for interning political dissidents such as communists and social-democrats. In 1934 these camps were placed under control of the S.S. After a public 
outcry in Germany that same year, Hitler closed most camps. The Nazi concentration system only began developing in 1936 when Himmler was made supreme head of the German police. As "L'idylle" was written in $1936,{ }^{9}$ it seems as though the primary context for this récit was the Soviet gulags.

${ }^{3}$ In Complexity in Maurice Blanchot's Fiction: Relations between Science and Literature (New York: Peter Lang, 1999), pages 125 to 155, I discuss a chiasmatic reading of "L'idylle."

${ }^{4}$ See my work, Politics and Literature: The Case of Maurice Blanchot (Peter Lang, 1999), where I discuss political aspects of "L'idylle." The short work was first published in 1947 after news of the Nazi Death Camps was made public, then in 1951 with "Le dernier mot" as Le ressassement éternel.

5 For Sarah Kofman, a Jewish intellectual who survived Auschwitz, "L'idylle" is a "fragment d'Auschwitz": "(Il) s'impose à moi, intellectuelle juive qui ait survécu à l'holocauste, de rendre hommage à Blanchot pour ces fragments sur Auschwitz épars dans ses textes, écriture de cendres, écriture du désastre qui évite le piège d'une complicité avec le savoir spéculatif, avec ce qui en lui relève du pouvoir, et est donc complice des tortionnaires d'Auschwitz" (Paroles suffoquées 13-14). See her interpretation of "L'idylle" on pages $21-41$.

${ }^{6}$ There is no evidence in Blanchot's many journalistic articles before this time that he was aware of Hitler's concentration camps. From 1933 to 1936 he wrote for La revue française, Le rempart, La revue du [XXX] siècle, Le journal des débats, and Combat. He protests against "Hitler's barbarous persecution of Jews" in 1933 ("Des violences antisémites à l'apothéose du travail," Le rempart 10 [May 1, 1933]: 3), but not in the context of concentration camps. "L'idylle" was written two years before Kristallnacht; the original context seems to have been the Soviet camps, which Blanchot extended "après coup" to Auschwitz.

${ }^{7}$ Blanchot points this out in Après-coup, page 94. In the later versions, the title has been shortened to "L'idylle."

${ }^{8}$ This follows the classic envelope pattern of the chiasmus, ABBA, in which the words of the sentence are inverted by repeating them in reverse order, preceded by "mais." Other patterns of inversion are interrogative or negative or express antithesis through antonyms or other lexical and syntactical opposition. 


\section{Bibliography}

Blanchot, Maurice. Après coup. Paris: Minuit, 1983.

. "L'idylle." La licorne (spring 1947): 33-58.

- Le ressassement éternel. Paris: Minuit, 1951.

"Des violences antisémites à l'apothéose du travail." Le rempart 10 (May 1, 1933): 3 .

Hess, Deborah. Complexity in Maurice Blanchot's Fiction: Relations Between Science and Literature. New York: Peter Lang, 1999.

. Politics and Literature: The Case of Maurice Blanchot. New York: Peter Lang, 1999.

Kofman, Sarah. Paroles suffoquées. Paris: Galilée, 1986. 